\title{
AN ASSESSMENT OF THE IMPORTANCE OF LANGUAGE SKILLS AND VOCABULARY KNOWLEDGE IN A FOREIGN LANGUAGE: THE CASE FOR SPORTS MANAGEMENT
}

\author{
Darija Omrčen
}

Faculty of Kinesiology, University of Zagreb, Croatia

\begin{abstract}
The assessed importance of each of the four basic language skills in a foreign language varies, and the relationship between a person's knowledge of vocabulary and the four macro language skills is highly elaborate in a foreign language of a particular profession, i.e. domain. In addition to the vocabulary in general language, a person must also master the knowledge of concepts that form the theoretical basis of the profession in question as well as the terms assigned to these concepts, first in one's native language and then in the foreign one. The first aim of the research in this paper was to determine how respondents assessed the import of each sub-skill within the four groups of basic language skills - reading, writing, listening and speaking on the one hand, and on the other to determine the weight of knowledge of sports management-specific terminology in a foreign language for working in sports management in the Republic of Croatia. The second objective was to establish, also in the context of sports management, the correlation between the estimated importance of each of the four language skills and the estimated importance of the knowledge of sports management-specific vocabulary. The sample consisted of 70 students (men: $n=44$; women: $n=26$ ) of the fourth and fifth study years at the Faculty of Kinesiology, the University of Zagreb. The students filled out a questionnaire consisting of 58 items. They rated the relevance of all the sub-skills within the four basic language skills with the highest ratings. As for the order of skills given their criticality, the results indicated that the subjects considered reading skills as the most important, followed by listening, speaking and finally writing. The respondents also assessed the significance of the command of sports management-specific vocabulary with the highest rating. However, contrary to expectations, the analysis pointed to a low or only marginally moderate correlation between the assessed merit of each of the four language skills and the assessed weight of knowledge of the sports management-specific vocabulary.
\end{abstract}

Key words: foreign language, language skills, managers, sport, vocabulary

\section{INTRODUCTION}

Numerous authors have depicted skills which successful managers should possess. For instance, Yukl (1998, 251-255) opines that to be efficient in their work,/ managers ought to master three sets of skills: conceptual, technical and communication ones. The last of these three skill groups is exceptionally portentous for a manager to be productive because

Submitted October $24^{\text {th }}, 2020$, accepted for publication January $16^{\text {th }}, 2021$

Corresponding author: Darija Omrčen. Faculty of Kinesiology, University of Zagreb, Horvaćanski zavoj 15 ,

10000 Zagreb, Croatia |E-mail: darija.omrcen@kif.unizg.hr 
interpersonal communication is one of the key managerial functions at all three management levels - top-level management, middle (tactical) management and operational (technical) management. Bartoluci $(2003,140)$ claims that communication is one of the seven fundamental managerial functions (planning, organizing, controlling, decision-making, communication, innovation and motivation). Language skills (Thitthongkam and Walsh 2010) and the command of foreign languages belong to the batch of communication skills indispensable for a manager's job in general (Dorożyński, Świerkocki and Urbaniak 2016), thus also for managers in the domain of sport, i.e. sport managers (Çiftçi and Mirzeoğlu 2014, $743)$. The results of the research conducted by Jovanova-Simeva $(2015,13)$ displayed among other things that the command of foreign languages contributes to the progress of modern sports management. In the research by Škorić (2018), the command of a foreign language ranked $7^{\text {th }}$ on the 12-level scale of competences essential for the work of sports managers.

Multiple studies addressing the prominence of language skills - reading, writing, listening and speaking, have been carried out for various domains. In the research by Al-Tamimi and Shuib $(2010,19)$ done among petroleum engineering students the average grade - on the scale anchored at 1 and 5, the latter being the highest - of listening in English as a foreign language for specific purposes was 4.284, reading 4.185, writing 4.140 and speaking 4.041. Prachanant's research (2012) demonstrated that employees working in tourism in Thailand graded the merit of the four basic language skills in the English language - also on the scale anchored at 1 and 5 - in the following descending order: speaking (4.46), listening (4.38), reading (3.87) and writing (3.68). On the other hand, in the research by Rajprasit et al. (2014) the Thai engineer-beginners did not assign the highest grades to any of the four language skills - on the assessment scale anchored at 1 and 4 (the latter being the highest) all average values were below 3 , and the sequence of skills in terms of their importance in the descending order was: reading (2.77), writing (2.69), speaking (2.56) and listening (2.53).

According to the research conducted in Taiwan by Wu and Chin (2010) with banking and financial sector employees the respondents regarded reading as the most important language skill in English as a foreign language, followed by listening, speaking and finally writing. In the research by Mohammadzadeh, Barati and Fatemi $(2015,1698)$ conducted with the employees in an Iranian bank $25 \%$ of the respondents regarded speaking and $20 \%$ regarded reading to be extremely necessary. Speaking and reading were assessed each by $50 \%$ of respondents to be very necessary for their work, followed by $25 \%$ of those who rated listening as very important and $10 \%$ of those who assigned the same magnitude to writing. As much as $85 \%$ of respondents opined that writing was necessary for their work.

Further, many authors who have researched into the general language addressed in their analyses the interconnection between the knowledge of vocabulary and the four basic languages skills - reading (Hsueh-chao and Nation 2000; Kaivanpanah and Zandi 2009; Laufer 1989, 1992, 1996, 2013; Laufer and Ravenhorst-Kalovski 2010; Nation 2006; Rashidi and Khosravi 2010; Schmitt, Jiang and Grabe 2011; Şen and Kuleli 2015), writing (Henriksen and Danelund 2015; Karakoç and Köse 2017; Matić and Bibić 2009; Yüksel 2015), then listening (Bonk 2000; Chang 2007; Nation 2006; Stæhr 2009; van Zeeland 2010; Teng, 2014) and finally speaking (Koizumi and In'nami 2013; Nation 2015). Stahl (2003, 241) claimed that vocabulary knowledge is the key predictor of text difficulty, i.e. the understanding of a text. Laufer (1989) testified to the fact that knowledge of $95 \%$ of vocabulary in a text was rudimentary for its understanding, and $\mathrm{Hu}$ and Nation (2000) asserted that knowledge of as much as $98 \%$ was required to understand a text. Schmitt, Jiang and Grabe (2011) reported that 
knowledge of $98-99 \%$ of the vocabulary appearing in a text was mandatory for a person to be able to independently read the text with understanding.

Anyhow, the association between vocabulary knowledge on the one hand and reading and listening on the other is reflected in the reverse direction as well - reading is also one of the ways to learn vocabulary (Nation 2015), and so is listening (Stæhr 2009; Zhang and Graham 2020). Milton's (2013) survey of research pointed to the medium to high correlation between vocabulary knowledge on the one hand and each of the four basic skills in a foreign language on the other. Harkio and Pietilä (2015) found a strong positive correlation between vocabulary knowledge (breadth and depth) and reading comprehension both for intermediate and advanced proficiency level L2 learners. Nevertheless, they opined that vocabulary breadth and depth appeared to have a somewhat lower positive correlation with reading comprehension skills in advanced level learners. The significance of vocabulary knowledge construct for reading was also confirmed by Qian (2008) who posited that vocabulary knowledge assists in decoding a text, thus it ultimately facilitates reading. Kiliç (2019) found vocabulary knowledge to correlate significantly both with performance in writing and speaking. However, Henriksen and Danelund (2015) reported on a rather contradictory result for general English as a foreign language as regards the interrelatedness between vocabulary knowledge and writing. According to their research finding, secondary school students scored extremely poorly on the receptive vocabulary test and performed surprisingly well on a 460-word long free essay writing task. True, their lexical error production relative to the essay length decreased as their vocabulary efficiency increased, i.e. these two performance aspects proved to be inversely proportional (Henriksen and Danelund 2015). As for the relevance of interrelation between vocabulary knowledge and the listening skill, van Zeeland and Schmitt (2012) found on a sample of native and non-native speakers that for appropriate listening comprehension the knowledge of $90 \%$ of vocabulary appeared to be imperative, and Ataş (2018) found a significant moderate correlation between vocabulary knowledge and listening comprehension. Uchihara and Clenton's (2020) research yielded rather perplexing results on the link between vocabulary knowledge with regard to its size and speaking. Namely, vocabulary size did not compulsorily occasion the production of lexically sophisticated words in L2 during the act of speech.

In foreign languages for specific purposes the association between vocabulary knowledge and the four macro language skills is particularly intricate. Apart from the knowledge of vocabulary in general language, learners must first master both the concepts comprising the theoretical basis of a domain and the terms assigned to these concepts in their mother tongue, and then the terms assigned to the corresponding concepts in the foreign language (cf. Hocenski-Dreiseidl 2006). In the author's informed opinion, research into the connection between vocabulary knowledge and certain basic language skills in the realm of language for specific purposes is rare. From this relatively scarce pool of analyses one was conducted by Xhaferi and Xhaferi $(2011,431)$ who found that regarding the language skills in English as a foreign language, specific terminology appeared to be an obstacle for successful communication, so that consequently vocabulary learning should be more conspicuous to be able to avoid this barrier. Dobreva and Popov's research (2013) evinced that speaking skills significantly affected vocabulary acquisition in the foreign (Bulgarian) language of medicine.

In the main, the relationship between vocabulary knowledge and language use proved to be reciprocal - vocabulary knowledge facilitates the use of language, and the use of language expands one's vocabulary (Nation 2001). 
To the best of the author's knowledge research data into how much the four macro language skills - reading, writing, listening and speaking - and specific-vocabulary knowledge are pivotal for work in sport management is scarce.

\section{METHODS}

The first aim of the research was to ascertain how the students - $44(62.9 \%)$ men and 26 (37.1\%) women (totalling 70 and averaging 23.5 years of age) - of the fourth and fifth study year at the Faculty of Kinesiology, the University of Zagreb (Croatia) assessed both the moment of each sub-skill within the sets of four macro, i.e. basic language skills reading, writing, listening and speaking - and the substance of English vocabulary signature for work in sports management in Croatia. The second aim within sports management as a reference domain was to scrutinize the connection between the estimated importance of the four basic language skills and the estimated importance of specific-vocabulary knowledge. The research results were expected to reveal viable implications for the development of guidelines in teaching foreign language for specific purposes to future sport managers. All the respondents learned English as their first foreign language.

In literature, listening, reading, writing and speaking are frequently referred to as language activities or as language skills (Jelaska 2005, 134). The latter term was opted for in this article. The term sub-skill was used to designate various sub-types of the four basic language skills. The students assessed both the relevance of 57 language sub-skills and the relevance of sport management-specific vocabulary in English as a foreign language on a Likert-type scale anchored at 1 (= not important at all) and 5 (extremely important). The 57 language sub-skills were allocated to four groups. The first group was comprised of nine reading sub-skills, the second group consisted of 19 writing sub-skills, the third contained eight listening sub-skills and the fourth 21 speaking sub-skills. All the language sub-skills were assessed in the context of using a foreign language (English) in a business situation. The importance of sports management specific-vocabulary knowledge in a foreign language was considered as a separate item.

Cronbach's $\alpha$ correlation coefficient was used to identify the reliability of the whole assessment tool as well as the reliability of each set of sub-skills. The Kolmogorov-Smirnov test revealed a significant departure from the normal distribution for all 58 manifest variables, i.e. items, which called for the use of nonparametric statistics for data processing. Nonparametric descriptive statistics of the variables encompassed median, mode, frequency of mode, minimal and maximal values, as well as the skewness and kurtosis of distributions for all variables. Next, the total average grades of all the sub-skills groups were calculated, together with the average grades per respondent for each sub-skill within each of the basic language skill clusters. The Spearman correlation coefficient $(\rho)$ was applied to identify at $p$ $<0.05$ significance level the interrelation between each basic language skill and the vocabulary knowledge variable. The data were processed by the statistical package Statistica for Windows, version 13.5.0.17. (TIBCO Software Inc. 2018). 


\section{RESULTS AND DISCUSSION}

The Cronbach's $\alpha$ correlation coefficient for the whole assessment tool was 0.966 . Such a high coefficient speaks in favour of the high reliability of the assessment tool applied. The Cronbach's $\alpha$ correlation coefficient for the set of items intended for the assessment of the importance of reading sub-skills was 0.879 , for the set of writing sub-skills 0.927 , for the set of listening sub-skills 0.831 and ultimately, for the set of speaking sub-skills 0.912 .

\subsection{Importance of reading, writing, listening and speaking for work in sport management in the Republic of Croatia}

The medians for the nine reading sub-skills revealed the assessment categories to be very similarly distributed on all nine variables. The students assessed eight sub-skills except reading and understanding technical literature written in a foreign language - most frequently to be extremely important (grade 5), and only slightly less frequently as very important (grade 4). They obviously opined that the sub-skill of reading and understanding technical literature written in a foreign language was not of the same critical moment for the work of a sports manager as the other reading sub-skills included in the assessment tool. This sub-skill was also the only one that received scores from across the whole assessment range, i.e. from the lowest (anchored at 1) to the highest (anchored at 5). As evident from Table 1, the distributions on all nine variables were negatively asymmetric, which suggests that all nine sub-skills were most frequently rated with high grades.

Table 1 Nonparametric descriptive statistics of nine reading sub-skills variables

\begin{tabular}{|l|c|c|c|c|c|c|c|}
\hline Variable & Median & Mode & $\begin{array}{c}\text { Freq. of } \\
\text { mode }\end{array}$ & Min & Max & Skew. & Kurt. \\
\hline $\begin{array}{l}\text { Reading and understanding a financial report } \\
\text { written in a foreign language by a co-worker in a } \\
\text { firm }\end{array}$ & 4.5 & 5 & 35 & 2 & 5 & -1.087 & 0.432 \\
\hline $\begin{array}{l}\text { Reading and understanding a business offer } \\
\text { written in a foreign language by a co-worker in a } \\
\text { firm }\end{array}$ & 5 & 5 & 43 & 2 & 5 & -1.376 & 1.572 \\
\hline $\begin{array}{l}\text { Reading and understanding a development } \\
\text { strategy (project, business activities, etc.) written } \\
\text { in a foreign language by a co-worker in a firm }\end{array}$ & 5 & 5 & 37 & 3 & 5 & -0.760 & -0.650 \\
\hline $\begin{array}{l}\text { Reading and understanding new ideas written in } \\
\text { a foreign language }\end{array}$ & 4.5 & 5 & 35 & 2 & 5 & -0.909 & 0.210 \\
\hline $\begin{array}{l}\text { Reading and understanding instructions written } \\
\text { in a foreign language }\end{array}$ & 4 & 5 & 34 & 3 & 5 & -0.611 & -0.574 \\
\hline $\begin{array}{l}\text { Reading and understanding an on-hand message } \\
\text { written in a foreign language }\end{array}$ & 5 & 5 & 36 & 3 & 5 & -0.716 & -0.689 \\
\hline $\begin{array}{l}\text { Reading and understanding official } \\
\text { letters/emails of general content written in a } \\
\text { foreign language }\end{array}$ & 5 & 5 & 41 & 3 & 5 & -0.852 & -0.235 \\
\hline $\begin{array}{l}\text { Reading and understanding an offer written in a } \\
\text { foreign language and sent by a business partner }\end{array}$ & 5 & 5 & 41 & 2 & 5 & -1.408 & 1.719 \\
\hline $\begin{array}{l}\text { Reading and understanding an offer written in a } \\
\text { foreign language by a co-worker in a firm } \\
\text { Legend: Freq - frequency, Min - minimal value, Max - maximal value, Skew.-skewness, Kurt. - kurtosis }\end{array}$ \\
\hline
\end{tabular}


In four of the nine reading sub-skills (reading and understanding a development strategy - project, business activities, etc. - written in a foreign language by a co-worker in a firm; reading and understanding instructions written in a foreign language; reading and understanding an on-hand message written in a foreign language; and reading and understanding official letters/emails of general content written in a foreign language) the lowest grade awarded was 3. This ultimately outlines the conjecture of students that reading in actual business situations appears to be somewhat more pertinent than reading technical literature in a foreign language, and that the latter might be regarded as a valuable yet supplementary asset. The greatest incidence of the highest grade $(5=$ extremely important) assigned to three reading sub-skills (reading and understanding official letters/emails of general content written in a foreign language; reading and understanding an offer written in a foreign language and sent by a business partner; reading and understanding a business offer written in a foreign language by a co-worker in a firm) points to the communication facet in which business deals are negotiated and potentially closed - in other words, the real supply and demand-related correspondence conveying key information for a business transaction in question. The average grade of the nine reading sub-skills totalled 4.379.

The medians and modes of 19 writing variables disclosed that most writing sub-skills received high grades (Table 2). Nevertheless, these grades although high were still noticeably lower than those received for the reading sub-skills, this being evidenced by no mode frequency exceeding 40, in contrast to the occurrence conspicuous of three reading sub-skills. Such a reaction of students might be elucidated as a two-facet response. On the one hand, writing is an indispensable and essential skill in a business environment. On the other hand, many people regard writing in a foreign language a skill very onerous to acquire (Gupta 1998), which could possibly have repercussions - although sometimes contradicting ones - on the multiplex writing anxiety construct (Cheng 2004). Hence, it might be hypothesized that writing anxiety and consequently potential avoidance of writing - as is the case, e.g., with the behavioural dimension of sport performance anxiety (cf. Smith and Smoll 1990) or test anxiety (Morris, Davis and Hutchings 1981) - could result in assigning the skill of writing a lower worth than reading in the context of sports management. As postulated by Cheng, Horwitz and Schallert (2008), the reading and writing constructs share the same common denominators - both draw on low self-confidence. Still, the true reasons for the aforesaid assessment sequel remain unclear in the current research, since opposing research results also exist - to exemplify, avoidance behaviour within the wider construct of writing apprehension was infrequent in the study conducted by Marzec-Stawiarska (2012) among adult advanced learners of English.

The total average assessment grade of all writing sub-skills was 4.183, i.e. it was slightly lower than the total average assessment grade of reading sub-skills. Yet, the writing sub-skills were awarded high grades, and the interpretation of such students' viewpoints might be sought in the awareness of the basic communication principle formulated by Harold $\mathrm{H}$. Lasswell (1948: 37): Who says what in which channel to whom with what effect? Namely, the curriculum of the sports management programme as a second major offered at the Faculty of Kinesiology, the University of Zagreb (Croatia) includes the course concerning communication in sports management within which the communication principles - Lasswell's included - are discussed and explored. True, since 1948 Lasswell's principle has been changed in that it has been complemented, elaborated, etc.

\footnotetext{
${ }^{1}$ Author's comment: communication channel.
} 
Notwithstanding, its essence has remained unaltered: both the context and the conditions in which communication develops between a sender and a receiver should be pondered to be able to infer the effects of a sent message.

Table 2 Nonparametric descriptive statistics of 19 writing sub-skills variables

\begin{tabular}{|c|c|c|c|c|c|c|c|}
\hline Variable & Median & Mode & $\begin{array}{c}\begin{array}{c}\text { Freq. of } \\
\text { mode }\end{array} \\
\end{array}$ & Min & Max & Skew. & Kurt. \\
\hline $\begin{array}{l}\text { Grammatical accuracy of writing in a foreign } \\
\text { language }\end{array}$ & 4 & 4 & 31 & 1 & 5 & -1.108 & 1.940 \\
\hline Writing letters/emails in a foreign language & 5 & 5 & 38 & 2 & 5 & -1.332 & 1.839 \\
\hline Writing a financial report in a foreign language & 4 & 5 & 30 & 1 & 5 & -1.161 & 1.846 \\
\hline $\begin{array}{l}\text { The skill of writing in a foreign language in } \\
\text { financial management in sport }\end{array}$ & 4 & 4 & 33 & 1 & 5 & -1.695 & 5.011 \\
\hline $\begin{array}{l}\text { The skill of writing in a foreign language in the } \\
\text { management of organizing sports events }\end{array}$ & 4 & 4 & 34 & 2 & 5 & -0.833 & 0.702 \\
\hline $\begin{array}{l}\text { The skill of writing in a foreign language in } \\
\text { planning the development of a sports } \\
\text { association/society }\end{array}$ & 4 & 4 & 36 & 2 & 5 & -0.358 & -0.182 \\
\hline $\begin{array}{l}\text { The skill of writing in a foreign language in } \\
\text { planning the development of a sports club }\end{array}$ & 4 & 4 & 39 & 2 & 5 & -0.754 & 0.628 \\
\hline $\begin{array}{l}\text { The skill of writing in a foreign language in the } \\
\text { management of human resources }\end{array}$ & 4 & 4 & 33 & 1 & 5 & -0.850 & 0.932 \\
\hline $\begin{array}{l}\text { The skill of writing in a foreign language in the } \\
\text { management of the promotion of sports- and } \\
\text { physical recreation-related offer in tourism }\end{array}$ & 5 & 5 & 39 & 2 & 5 & -1.316 & 1.212 \\
\hline $\begin{array}{l}\text { The skill of writing in a foreign language in the } \\
\text { management of a sports facility }\end{array}$ & 4 & 4 & 31 & 1 & 5 & -0.857 & 0.801 \\
\hline $\begin{array}{l}\text { Written transfer of someone's message in a } \\
\text { foreign language to a third party }\end{array}$ & 4 & 5 & 31 & 1 & 5 & -1.345 & 2.339 \\
\hline $\begin{array}{l}\text { Written delivery of instructions in a foreign } \\
\text { language }\end{array}$ & 4 & 5 & 30 & 2 & 5 & -0.647 & -0.363 \\
\hline $\begin{array}{l}\text { Presenting in a written form the comparative } \\
\text { advantages (e.g., of a tourist destination, sports } \\
\text { activity, sports organization, etc.) in a foreign } \\
\text { language }\end{array}$ & 4 & 4 & 31 & 2 & 5 & -0.844 & 0.440 \\
\hline $\begin{array}{l}\text { Motivating in a written form in a foreign } \\
\text { language }\end{array}$ & 4 & 4 & 31 & 2 & 5 & -0.366 & -0.543 \\
\hline $\begin{array}{l}\text { The skills of written diplomatic communication } \\
\text { in a foreign language }\end{array}$ & 4 & 5 & 29 & 2 & 5 & -0.587 & -0.495 \\
\hline Written persuading in a foreign language & 4 & 4 & 31 & 2 & 5 & -0.891 & 0.490 \\
\hline Written accuracy in a foreign language & 4 & 4 & 33 & 2 & 5 & -0.561 & -0.151 \\
\hline $\begin{array}{l}\text { Drawing up a development strategy (a project, } \\
\text { business transactions, etc.) in a foreign } \\
\text { language }\end{array}$ & 4 & 4 & 30 & 2 & 5 & -0.674 & -0.097 \\
\hline $\begin{array}{l}\text { Writing/drawing up an offer in a foreign } \\
\text { language }\end{array}$ & 4 & 4 & 33 & 2 & 5 & -0.793 & 0.471 \\
\hline
\end{tabular}

Legend: Freq. - frequency, Min - minimal value, Max-maximal value, Skew. - skewness, Kurt. - kurtosis 
As for the skill of writing, the word says may be substituted with the word writes. Since the domain under consideration here is sports management, further elucidation ought to be correlated with the roles of managers on each of the three possible management levels. To exemplify, one of the roles of top management is the preparation of strategic plans and company policy. This preparation most probably does not develop in a foreign language. Still, due to the society's globalization on the whole and due to the presence of participants from all over the world, for example, in multinational companies, it is possible that during the development of strategy plans a share of communication - either oral or written develops in a foreign language. Owing to this varying structure of top management and the fluctuating language-related circumstances, the sub-skills of writing a developmental strategy in a foreign language received a lower grade than writing a letter/an email (Table 2). Considering that one of the roles of middle or tactical management is to send central reports and data to top management, and the term sending might be perceived in the realm of the research in this article as sending written reports, the international structure of some companies subsumes knowledge of a foreign language - usually English - and subsequently also writing important reports in a second language. In such a context, the fact that one of the tasks of the members of the so-called operational, i.e. technical management, is - among many - the preparation of periodic reports on the work of lower-level employees, this again implies the skill of writing. Thus, given their role, the members of middle and top management most often have an opportunity to communicate with their superiors by writing in a foreign language. Explicitly, one of the roles of top management members is to maintain contact with the outside world. This presupposes written communication in a foreign language, whereas members of middle management in a company that may have foreign employees must communicate in writing both with top and operational management.

Another skill that received high marks was the skill of writing in a foreign language in managing the promotion of a sport and physical recreation-related offer in tourism. Such a result was expected because today's Croatian, but also global, tourism is inconceivable without a command of foreign languages, writing skills included. The writing skills that some of the respondents rated the lowest were grammatical accuracy, writing a financial report, writing skills in a foreign language in financial management in sports and human resources management as well as in sports facility management or conveying someone's message to a third party. In other words, the results for grammatical precision proved that the respondents considered it to be less pertinent for the business context. Still, this does not mean that grammar should be considered as extraneous and inconsequential in specific business conditions. Namely, language for specific purposes has its own functional grammar (Nagy 2014, 269) which - in addition to vocabulary, learning skills, register, discourse and genre (Dudley-Evans and St John 1998, 5) - is one of its key features. The reasons for the estimated somewhat lesser germane of grammatical correctness can only be speculated. But, it is beyond doubt that many who learn any foreign language find grammar difficult to master, and this is because it is, as expounded by DeKeyser $(2005,3)$, a complex construct that encompasses forms, meaning and the connection between them. Additionally, teaching English by extensively focusing on grammar and not on, for example, intercontextual application is considered to be an obsolete and outdated method (Basta 2017, 554).

The remaining four hitherto mentioned sub-skills - writing a financial report, writing skills in a foreign language in financial management in sports, human resources management, sports facility management and conveying someone's message to a third person - obviously in the opinion of some respondents do not always require the knowledge of (a) foreign language(s). 
Eventually, some respondents considered them completely irrelevant for work in sports management. Nevertheless, this does not mean that the command of (a) foreign language(s) is peripheral for work, for example, in human resource management since there are companies that put the knowledge of business foreign language on the list of competency development programmes within human resource management (cf. Bartolić and Prelas Kovačević 2011, 87). True, this information does not disclose anything about the skill of writing in a foreign language, but it is illustrative for the area of management in the specified domain. As with reading skills, the distributions on all 19 variables were markedly negatively asymmetric, i.e. the respondents most often rated the criticality of all sub-skills with the highest marks.

Listening is the first skill to be developed when a child starts to acquire his/her mother tongue (Patekar 2013, 293), and it is also an outstandingly demanding skill in mastering another (foreign) language (Patekar 2013, 299). As to the listening sub-skills in the current study, Table 3 evinces median and mode values similar to those for writing sub-skills. Yet, while the minimum value of the modes was not less than 4 in any of the writing skills, this was the case with the two listening sub-skills in a business-related context - understanding an oral message in a foreign language on the one hand and understanding orally delivered instructions in a foreign language on the other. In other words, the first sub-skill mentioned referred to the discerning of orally communicated messages in general.

Table 3 Nonparametric descriptive statistics of eight listening sub-skills variables

\begin{tabular}{|l|c|c|c|c|c|c|c|}
\hline Variable & Median & Mode & $\begin{array}{c}\text { Freq. of } \\
\text { mode }\end{array}$ & Min & Max & Skew. & Kurt. \\
\hline $\begin{array}{l}\text { Understanding new ideas orally expressed in a } \\
\text { foreign language }\end{array}$ & 4 & 4 & 32 & 2 & 5 & -1.089 & 1.231 \\
\hline $\begin{array}{l}\text { Understanding instructions orally expressed in } \\
\text { a foreign language }\end{array}$ & 4 & 5 & 32 & 3 & 5 & -0.549 & -0.719 \\
\hline $\begin{array}{l}\text { Understanding a message orally expressed in a } \\
\text { foreign language }\end{array}$ & 4.5 & 5 & 35 & 3 & 5 & -0.629 & -0.523 \\
\hline $\begin{array}{l}\text { Understanding comparative advantages (e.g., } \\
\text { of a tourist destination, sports activity, sports } \\
\text { organization, etc.) orally expressed in a } \\
\text { foreign language }\end{array}$ & 4 & 4 & 34 & 1 & 5 & -1.388 & 4.091 \\
\hline $\begin{array}{l}\text { Understanding criticism orally expressed in a } \\
\text { foreign language }\end{array}$ & 4 & 5 & 33 & 2 & 5 & -0.836 & 0.159 \\
\hline $\begin{array}{l}\text { Understanding a financial report orally } \\
\text { presented in a foreign language }\end{array}$ & 4.5 & 5 & 35 & 1 & 5 & -1.544 & 3.383 \\
\hline $\begin{array}{l}\text { Understanding a business offer orally } \\
\text { expressed in a foreign language }\end{array}$ & 4 & 4 & 38 & 1 & 5 & -1.493 & 4.542 \\
\hline $\begin{array}{l}\text { Understanding a development strategy (a } \\
\text { project, business transactions, etc.) orally } \\
\text { expressed in a foreign language }\end{array}$ & 4 & 4 & 37 & 1 & 5 & -1.490 & 3.587 \\
\hline
\end{tabular}

Legend: Freq. - frequency, Min - minimal value, Max-maximal value, Skew. - skewness, Kurt. - kurtosis

Consequently, all other sub-skills in that segment of the assessment tool could be interpreted as its sub-types. Nonetheless, one of them stands out, and that is the understanding of instructions delivered orally in a foreign language - all respondents obviously regarded the comprehension of oral instructions as the most far-reaching sub-type of comprehending orally expressed messages. According to previous research, numerous 
problems arise when trying to fathom a text orally delivered by a second party. These problems range from the need to recognize sounds and words and subsequently the need to create a mental image of a word, to the non-comprehension of the whole message (Goh 2000). Hence, the result in the current research on the weightiness of listening comprehension presumably results from the awareness of the need to overcome some of the impending problems listed.

The overall average rating of the substance of listening sub-skills was 4.295 , thus justifying the ordained conclusion that on the whole the respondents considered the listening skill to be more critical than the writing skill in the context of sports management, but less seminal than the reading skill. However, the negative distribution asymmetry on all eight listening variables (sub-skills), as in the two previous cases, showed that the respondents rated all listening skills also most often with the highest marks.

Although the respondents rated all speaking sub-skills most frequently with high marks (Table 4) as well, the number of sub-skills that received, among other grades, the lowest grade as regards their merit from some respondents $(45.4 \%)$ was very similar to the number of listening sub-skills $(50 \%)$ rated by some respondents as the lowest with regard to their upside for work in sports management. The highest frequency of the apical importance grade was found for the speaking sub-skills variables the skill of speaking in a foreign language in business negotiations $(\mathrm{n}=41)$ and the skill of calm oral communication in a foreign language, even when a business situation is stressful $(\mathrm{n}=40)$. Such a result unequivocally reveals that business negotiations and calm communication - which in other words implies the ability to control the communication mode - were in the opinion of the respondents among the quintessential factors in oral communication.

The overall average rate of the prominence of all speaking sub-skills was 4.231 - in other words, only the skill of writing received a lower overall grade. The highest values both of medians and modes were obtained for only four speaking sub-skills - the variable that relates to the account of the speaking skill in a foreign language in the management of organizing a sports event, i.e. a competition, followed by the variable regarding the skill of speaking in the context of business negotiations, the variable assessing the significance of the speaking skill in managing the promotion of the sports- and physical recreation-related offer in tourism as well as the variable assessing the relevance of being calm during oral communication in a foreign language.

As for the first variable previously listed, the statistical results in terms of medians and modes are closely related with the success of Croatian athletes - both individual and sports teams - on the global sports scene on the one hand, and on the other, with the increasing number of international sports competitions hosted by Croatia. According to Milanović, Čustonja and Hrženjak $(2016,41)$, the notion of sport is in the Croatian society traditionally envisioned in the context of sports contests, and sport and sporting performance are simultaneously the expression of the society itself as well (Milanović, Čustonja and Hrženjak 2016, 42). In their article Milanović, Čustonja and Hrženjak $(2016,42)$ further opine that the achievements of Croatian athletes contribute to the promotion of Croatia on a global level. With reference to communication, Beech and Chadwick (2010, cited in Peručić and Joković 2018 , 22) posit that sport must communicate with prospective consumers. Hence, sports competitions are one type of communication media (Peručić and Joković 2018, 22) encompassing communication in all its facets - be it through reading, writing, listening or speaking. 
Table 4 Nonparametric descriptive statistics of 21 speaking sub-skills variables

\begin{tabular}{|c|c|c|c|c|c|c|c|}
\hline Variable & Median & Mode & $\begin{array}{c}\text { Freq. of } \\
\text { mode }\end{array}$ & Min & $\operatorname{Max}$ & Skew. & Kurt. \\
\hline $\begin{array}{l}\text { The skill of speaking in a foreign language in } \\
\text { financial management in sport }\end{array}$ & 4 & 4 & 34 & 1 & 5 & -1.294 & 3.004 \\
\hline $\begin{array}{l}\text { The skill of speaking in a foreign language in } \\
\text { sports event organization management }\end{array}$ & 5 & 5 & 39 & 1 & 5 & -1.411 & 2.374 \\
\hline $\begin{array}{l}\text { The skill of speaking in a foreign language in } \\
\text { planning the development of a sports } \\
\text { association/society }\end{array}$ & 4 & 4 & 30 & 1 & 5 & -0.957 & 1.145 \\
\hline $\begin{array}{l}\text { The skill of speaking in a foreign language in } \\
\text { planning the development of a sports club }\end{array}$ & 4 & 4 & 35 & 1 & 5 & -0.877 & 1.623 \\
\hline $\begin{array}{l}\text { The skill of speaking in a foreign language in } \\
\text { business negotiations }\end{array}$ & 5 & 5 & 41 & 1 & 5 & $-1.522 \mid$ & 2.397 \\
\hline $\begin{array}{l}\text { The skill of speaking in a foreign language in } \\
\text { human resources management }\end{array}$ & 4 & 4 & 30 & 2 & 5 & -0.914 & 0.478 \\
\hline $\begin{array}{l}\text { The skill of speaking in a foreign language in } \\
\text { managing the promotion of sport- and physical } \\
\text { recreation-related offer in tourism }\end{array}$ & 5 & 5 & 39 & 1 & 5 & -1.782 & 3.851 \\
\hline $\begin{array}{l}\text { Grammatical accuracy when speaking in a } \\
\text { foreign language }\end{array}$ & 4 & 4 & 39 & 2 & 5 & -0.845 & 1.361 \\
\hline $\begin{array}{l}\text { Pronunciation when speaking in a foreign } \\
\text { language }\end{array}$ & 4 & 4 & 28 & 2 & 5 & $-0.150 \mid$ & -0.867 \\
\hline Answering questions in a foreign language & 4 & 5 & 32 & 1 & 5 & -1.463 & 3.331 \\
\hline $\begin{array}{l}\text { Orally discussing various matters in a foreign } \\
\text { language }\end{array}$ & 4 & 4 & 33 & 2 & 5 & -1.064 & 1.233 \\
\hline $\begin{array}{l}\text { Oral presentation of a business project in a } \\
\text { foreign language }\end{array}$ & 4 & 5 & 33 & 2 & 5 & -0.931 & 1.093 \\
\hline $\begin{array}{l}\text { Delivering oral instructions in a foreign } \\
\text { language }\end{array}$ & 4 & 4 & 38 & 2 & 5 & -0.533 & 0.324 \\
\hline Giving advice in a foreign language & 4 & 4 & 36 & 2 & 5 & -0.584 & 0.230 \\
\hline $\begin{array}{l}\text { Orally expressing comparative advantages } \\
\text { (e.g., of a tourist destination, sports activity, } \\
\text { sports organization, etc.) in a foreign language }\end{array}$ & 4 & 4 & 34 & 2 & 5 & -0.851 & 1.051 \\
\hline $\begin{array}{l}\text { Oral communication in a foreign language } \\
\text { using various types of telephones }\end{array}$ & 4 & 4 & 38 & 2 & 5 & -0.896 & 1.128 \\
\hline Asking questions in a foreign language & 4 & 4 & 33 & 1 & 5 & -1.507 & 4.651 \\
\hline $\begin{array}{l}\text { Humour in oral business communication in a } \\
\text { foreign language }\end{array}$ & 4 & 4 & 30 & 1 & 5 & -1.048 & 1.165 \\
\hline $\begin{array}{l}\text { The skill of diplomatic oral communication in a } \\
\text { foreign language }\end{array}$ & 4 & 5 & 33 & 1 & 5 & -1.528 & 3.117 \\
\hline $\begin{array}{l}\text { Intercultural communication skills in a foreign } \\
\text { language }\end{array}$ & 4 & 4 & 32 & 2 & 5 & -0.404 & -0.431 \\
\hline $\begin{array}{l}\text { The skill of calm oral communication in a } \\
\text { foreign language, even when a business } \\
\text { situation is stressful }\end{array}$ & 5 & 5 & 40 & 2 & 5 & -1.311 & 2.737 \\
\hline
\end{tabular}

Legend: Freq. - frequency, Min - minimal value, Max - maximal value, Skew. - skewness, Kurt. - kurtosis

A valid statistical comparison demands the application of the same methodology (population, sample, assessment tool, statistical methods) in juxtaposed analyses, which 
was not the case with the past research and the research presented in this text. However, the results in the current research were contrasted with the research results obtained by other authors to exemplify - at least to some extent - the imminent tenors in this respect. Subsequently, undeterred by the lack of prerequisites for accurate comparison, Table 5 still provides an interesting overview which allows for several viable conclusions. First and foremost, the order of importance of skills in the current research manifests as being reading, listening, speaking and lastly writing (Table 5). Such a concatenation stems from the roles of managers and their activities at various management levels. Furthermore, the contemporary ways of communication, i.e. communication channels or paths effectuate written communication through miscellaneous ways of the contemporary digital era - emails being seemingly the most customary in corporate communication (cf. Szabó 2014). Therefore, reading might be highlighted to be of utmost salience in this respect. What lacks in this string, however, is the parallel precedence of writing in the reading-writing chain of events. The reasons for such an outcome are believably to be found in the collective value of the estimation of the total writing skill cluster, which clouds to a certain extent the standing of the item (cf. Table 2) appertaining to the skill of writing letters/emails in L2.

Table 5 Order of importance in terms of average values of the four basic language skills in previous and current research

\begin{tabular}{|c|c|c|c|c|c|c|}
\hline \multirow[t]{2}{*}{ Author(s) } & \multirow[t]{2}{*}{ Subjects } & \multirow[t]{2}{*}{ Scale } & \multicolumn{4}{|c|}{$\begin{array}{c}\text { Four Basic Language Skills } \\
\text { by their Assessed Importance }\end{array}$} \\
\hline & & & $1^{\mathrm{st}}$ & $2^{\text {nd }}$ & $3^{\text {rd }}$ & $4^{\text {th }}$ \\
\hline $\begin{array}{l}\text { Current } \\
\text { research }\end{array}$ & $\begin{array}{l}\text { kinesiology } \\
\text { students (Croatia) }\end{array}$ & $\begin{array}{l}-5 \text { importance scale for } \\
\text { work in sport management }\end{array}$ & \begin{tabular}{|l|} 
reading \\
$(4.379)$ \\
\end{tabular} & \begin{tabular}{|l|} 
listening \\
$(4.295)$
\end{tabular} & \begin{tabular}{|l} 
speaking \\
$(4.231)$
\end{tabular} & $\begin{array}{l}\text { writing } \\
(4.183)\end{array}$ \\
\hline $\begin{array}{l}\text { Al-Tamimi } \\
\& \text { Shuib } \\
\text { (2010) }\end{array}$ & $\begin{array}{l}\text { petroleum } \\
\text { engineering } \\
\text { students (Yemen) }\end{array}$ & $\begin{array}{l}1-5 \\
\text { importance scale }\end{array}$ & $\begin{array}{l}\text { listening } \\
(4.258)\end{array}$ & $\begin{array}{l}\text { reading } \\
(4.185)\end{array}$ & $\begin{array}{l}\text { writing } \\
(4.140)\end{array}$ & $\begin{array}{l}\text { speaking } \\
(4.041)\end{array}$ \\
\hline $\begin{array}{l}\text { Prachanant } \\
\text { (2012) }\end{array}$ & $\begin{array}{l}\text { employees in } \\
\text { tourism (Thailand) }\end{array}$ & \begin{tabular}{|l|}
$1-5$ \\
the English language skills \\
need of tourism employees
\end{tabular} & $\begin{array}{l}\text { speaking } \\
(4.48)\end{array}$ & $\left|\begin{array}{l}\text { listening } \\
(4.38)\end{array}\right|$ & $\begin{array}{l}\text { reading } \\
(3.87)\end{array}$ & $\begin{array}{l}\text { writing } \\
(3.68)\end{array}$ \\
\hline $\begin{array}{l}\text { Rajprasit } \\
\text { et al. } \\
(2014)\end{array}$ & $\begin{array}{l}\text { engineer-beginners } \\
\text { (Thailand) }\end{array}$ & \begin{tabular}{|l|}
$1-4$ \\
English \\
language skills needed for \\
effective communication in \\
engineering workplace
\end{tabular} & $\begin{array}{l}\text { reading } \\
(2.77)\end{array}$ & $\begin{array}{l}\text { writing } \\
(2.69)\end{array}$ & $\begin{array}{l}\text { speaking } \\
(2.56)\end{array}$ & $\begin{array}{l}\text { listening } \\
(2.53)\end{array}$ \\
\hline $\begin{array}{l}\text { Kuna } \\
(2007)\end{array}$ & $\begin{array}{l}\text { humanities and } \\
\text { social sciences } \\
\text { students (Croatia) }\end{array}$ & $\begin{array}{l}\text { in \% regarding necessity } \\
\text { for future employment }\end{array}$ & $\begin{array}{l}\text { speaking } \\
(58 \%)\end{array}$ & $\begin{array}{l}\text { reading } \\
(22 \%)\end{array}$ & $\begin{array}{l}\text { listening } \\
\text { writing (1 } \\
\text { each) }\end{array}$ & $\begin{array}{l}\mathrm{d} \\
\%\end{array}$ \\
\hline
\end{tabular}

The key cause of the obtained differences between the estimated values of language skills presented in Table 5 lies in the type of a job, i.e. domain in which each research was conducted. The respondents obviously had divergent opinions about the order of language skills in terms of their importance for a particular occupation, and accordingly they prioritized those skills that they either anticipated (students as respondents - cf. AlTamimi and Shuib 2010, Kuna 2007, current research) or experientially recognized, e.g. employees in tourism (Prachanant 2012) and engineer-beginners (Rajprasit et al. 2014), as the most needed ones. Setting aside the fact that the relevance of the four basic language skills was found to vary in order in all studies displayed in Table 5, there are 
still some common points that need to be scrutinized in more detail. First, both in the research conducted by Al-Tamimi and Shuib (2010) and in the current research the average grade for all four language skills was above 4, i.e. the second highest grade possible. Secondly, although the obtained order of importance of the four basic language skills was disparate in the two aforementioned studies, the discord in the sequence is the result of minimal differences among average values. Third, the dissimilarity in the average value of the listening skill in the current research and in the research by AlTamimi and Shuib (2010) was negligible. This consequently implies that both the students of kinesiology and the students of petroleum engineering seem to expect to be proficient both in reading and writing in a foreign language once they begin their expert careers. Still, the opinion of engineer-beginners (Rajprasit et al. 2014) was somewhat different - they deemed reading to be the most important skill as did the students of kinesiology in the current research, unlike the engineering students from the study conducted by Al-Tamimi and Shuib (2010). Additionally, the novice engineers ranked writing as the second most important skill, whereas the kinesiology students considered it to be the least relevant for work in sports management, and the petroleum engineering students saw it as the second to last considering its weightiness for future work in the domain of petroleum engineering. Interestingly, the current research demonstrated a high materiality of listening, which seems to be somewhat incompatible to the viewpoint expressed by Dabic $(2014,1828)$ that listening is frustrating for students due to the lack of rules to be applied for listening comprehension and to the viewpoint (Marinković and Pešić 2015, 398) that listening comprehension belongs to the set of those processes that are least understood by scientists, and ultimately the most challenging to acquire. Further, the first-year students of the Faculty of Humanities and Social Sciences in Osijek (Croatia) were of the opinion that the most momentous skill - in terms of foreign language - they might need in future work would be speaking, followed by reading, writing and finally listening (Kuna 2007, 33-34). Curiously, their opinion as prospective jobholders in the domains of humanities and social sciences concurred with that of the employees in tourism (cf. Prachanant 2012). While the former forecast the need to be proficient in speaking in a foreign language, the latter had already witnessed the necessity for the proficiency of the skill in speaking in a domain which nowadays (excluding 2020 due to the COVID 19 pandemic) represents the world's third largest export category (1.7 trillion dollars in revenues as of 2018) behind fuels and chemicals (UNWTO 2019) - in which communication, predominantly in English in international communication, is of the utmost pertinence in transmitting information (cf. Wilson 2018).Several other studies that could not be compared in any way with those in Table 5 owing to a completely different research design, still allowed for at least some level of comparison, so that in the matter of the language skills rated the highest namely, reading - the results obtained in the current research compare to Wu and Chin's (2010) and Rajprasit et al.'s (2014) research.

\subsection{Importance of knowledge of specific vocabulary in a foreign language for work in sports management in the Republic of Croatia and its correlation with four basic language skills}

Table 6 shows that the median and mode values of the assessed crucial knowledge of specific terminology in a foreign language for work of sports managers were the highest possible. 
Table 6 Nonparametric descriptive statistics of the variable knowledge of sports management-specific vocabulary in a foreign language

\begin{tabular}{|l|c|c|c|c|c|c|c|}
\hline Variable & Median & Mode & Freq. of mode & Min & Max & Skew. & Kurt. \\
\hline $\begin{array}{l}\text { Knowledge of sports management-specific } \\
\text { vocabulary in a foreign language }\end{array}$ & 5 & 5 & 38 & 2 & 5 & -1.081 & 0.379 \\
\hline
\end{tabular}

Legend: Freq. - frequency, Min - minimal value, Max - maximal value, Skew. - skewness, Kurt. - kurtosis

As already said, the knowledge of vocabulary is mandatory for the development of each of the four basic language skills. Therefore, the next step in the analysis was to look into the relationship among the assessed importance of the knowledge of sports managementspecific vocabulary and the four basic language skills. To identify the size of this correlation ${ }^{2}$, the average grade of the assessment of each sub-skill within each basic skill cluster was calculated per each respondent. The Kolmogorov-Smirnov normality test revealed that the distribution of average values did not deviate significantly from the normal distribution. Since this test indicated that the results on the variable concerning the relevance of knowledge of sports management-specific vocabulary did deviate from the normal distribution curve, Spearman R correlation coefficient $(\rho)$ which is less/not sensitive to the distribution type was used to detect the size of the correlation among the average values for sports management specific-vocabulary knowledge and the four language skills at a significance level of $\mathrm{p}<0.05$. The results evidenced all the correlation coefficients to be significant at the set significance level. However, the correlation between the variable designating the moment of sports management specific-vocabulary knowledge and the amalgamated reading skill variable appeared to be very low $-\rho=0.340$ (Table 7), i.e. the statistical significance of this correlation confirmed it to be fair (for the ranges of the correlation size compare Colton 1974, 211) $)^{2}$.

Table 7 Spearman rank order correlations - four basic language skills x sports management specific-vocabulary knowledge

\begin{tabular}{|l|c|c|c|c|c|}
\hline Variable & Reading & Writing & Listening & Speaking & $\begin{array}{l}\text { Vocabulary } \\
\text { knowledge }\end{array}$ \\
\hline Reading & 1.000 & 0.737 & 0.647 & 0.677 & 0.340 \\
\hline Writing & 0.737 & 1.000 & 0.698 & 0.773 & 0.505 \\
\hline Listening & 0.647 & 0.698 & 1.000 & 0.687 & 0.462 \\
\hline Speaking & 0.677 & 0.773 & 0.687 & 1.000 & 0.480 \\
\hline Vocabulary knowledge & 0.340 & 0.505 & 0.462 & 0.480 & 1.000 \\
\hline
\end{tabular}

The results yielded for the relatedness between vocabulary knowledge on the one hand, and reading and writing skills on the other in the current analysis were only partly in accord with the results reported by some researchers (cf. Karakoç and Köse 2017) for general English as a foreign language regarding the impact of vocabulary knowledge on reading and writing. Whereas in the current research the correlation between the merit of vocabulary knowledge and the reading skill was significant but fair and on the lower border of moderate for the writing skill, in the analysis conducted by Karakoç and Köse

${ }^{2}$ Colton's $(1974,211)$ size of correlations is interpreted in the following way: $r=0$ to \pm 0.25 : no or negligible correlation; $r= \pm 0,25$ to $\pm 0,50$ : fair correlation; $r= \pm 0,50$ to $\pm 0,75$ : moderate-to-good correlation; $r= \pm 0,75$ to \pm 1 : very good-to-excellent correlation. 
(2017) the interrelation between lexical proficiency and both reading and writing was fair, the latter being not close to the lower level of being moderate. Although vocabulary knowledge in the present analysis was not tested in terms of its breadth and length, the yielded relatively low (fair) correlation as assessed by the respondents between the significance of vocabulary knowledge and the reading skill can be substantiated by the find obtained by $\mathrm{Li}$ (2015) who found a positive but moderate association between the constructs of vocabulary breadth and depth and reading comprehension.

On the other hand, such an assessment result is not in compliance with the past research conducted for general language on the value of vocabulary knowledge. For instance, Milton's (2013) review of research showed a moderate to high correlation between vocabulary knowledge and the proficiency in each of the four basic language skills. However, the analysis in the current research showed the assessed merit of vocabulary knowledge - with reference to Colton's correlation size scale - to be only fairly to moderately correlated with them. To specify, the correlation between the assessed relevance of vocabulary knowledge and the import of the writing skill was on the border between fair and moderate $-\rho=0.505$, whereas the correlations with the magnitude of speaking $(\rho=0.480)$ and listening $(\rho=0.462)$, although close to the cut-off point of being moderate, were only fair, as was the correlation with the reading skill $(\rho=0.340)$. To continue, the results yielded in the current research as regards the weightiness both of vocabulary knowledge and language skills as assessed by future kinesiologists were also not in compliance with the results of past research into the perceived interconnection of vocabulary knowledge and the skill of speaking. In contrast with Koizumi and In'nami (2013), Schmitt (2010) and many others who testified to the interdependence between the constructs of vocabulary knowledge and speaking, the results of the current analysis revealed a positive but only fair relation between them as obtained on the basis of the respondents' assessment.

The reasons for the obtained correlations between the construct of vocabulary knowledge on the one hand and the four primary language skills on the other - on the basis of students' assessments regarding the bearing of these constructs for work in sports management - might be sought in several aspects. The first and most probably the key one was methodology regarding vocabulary knowledge deliberation. Namely, it is plausible that some of the discrepancies between the listed results in the current research and the analyses in general language occurred due to the fact that here the investigation looked into the relevance of sports management specific-vocabulary knowledge, where the notion of sports managementspecific vocabulary was not broken down into further sub-items (e.g., vocabulary depth and breadth, receptive and productive vocabulary). Varieties in the interpretation of this item were therefore plausible, possible and probable. Be as it may and regardless of the depletion of elaborateness of the vocabulary knowledge construct-related battery of ostensive items in the assessment tool applied, transmitting somebody's message in writing to a third party, giving instructions in a business context, i.e. in a business situation, the skill of tactful (diplomatic) written communication and the like cannot in any way operate without vocabulary knowledge. This notion of vocabulary knowledge characteristic for sports management and used by sports managers implies vocabulary which neither in terms of business language nor in terms of kinesiological terminology in a foreign language relates to considerable vocabulary depth, but remains relatively on the surface level of vocabulary knowledge in language for specific purposes. In other words, this means that sports managers do not discuss with their business partners such details as the amount of blood lactate in blood during physical exercises at various intensities, which would require accurate knowledge of 
the terminology of biomechanics ${ }^{3}$, economics ${ }^{4}$, physiology of exercise and sport-related ${ }^{5}$ and sports-medical terminology together with terminology particular to the theory of training. When it comes to sport, a sports manager might deliberate about various types of sports, multifarious sport-related programmes, the financial aspects of sport- or physical recreation-related offer, etc. The level of vocabulary knowledge although rather demanding still does not solicit exhaustive lexical cognizance of the domain that encompasses sport, physical exercise, management, business transactions, etc. Ultimately, in a foreign language a sports manager might need such terms that are not highly technical, i.e. terminology necessary in the domain of sport management would in all probability be of a somewhat lower technical level. Such terms in the context of business communication could be names of sports and sports events like football ${ }^{6}$ or basketball ${ }^{7}$, as well as the terms like offer ${ }^{8}$, demand ${ }^{9}$ or development strategy $y^{10}$ that are characteristic for the domain of economics. It would be probably credible to conclude that names of sports - although undoubtedly of a somewhat lower level of technical specificity in the language register of kinesiology, the science of human movement, than, for example, the term excess post-exercise oxygen consumption (or EPOC) - are words that can be learned in a general language. Such a conclusion could be drawn on the grounds of sport being a global social phenomenon, at least as far as the names of sports are concerned, known to a wide(r) public. Be that as it may, such a supposition could immediately stumble into the pitfall of misconception. One example will suffice to justify the previous contention. This example has been taken from the domain of Croatian tourism promotion and it deals with two terms - i.e. the names of two sports - that are (too) frequently incorrectly used either in the Croatian language or by native speakers of Croatian who use English as a foreign language. The two terms in question are surfing $^{11}$ and windsurfing ${ }^{12}$. Their correct translation equivalents in Croatian are jahanje na valovima and jedrenje na dasci, respectively. In a brochure published in the Croatian language by the Croatian National Tourist Board (2018) the terms that appear in the text are windsurfing, daskanje and daskanje na vjetru. The first of the three is a foreign (English) word in Croatian and the other two belong to jargon. Ultimately, it is not clear which sport(s) these three terms actually refer to, since when used like that, they appear to refer to three different sports. Nonetheless, they in fact refer to two sports: windsurfing as daskanje na na vjetru refers to windsurfing, and the second term - daskanje - to surfing. To explain to non-Croatian speakers, daska in Croatian means a board. Hence, the ad litteram (and simultaneously incorrect) translation of the word daskanje into English would be

\footnotetext{
${ }^{3}$ Some terms used in biomechanics are: English displacement, Croatian pomak, German Verschiebung; English torque, Croatian moment sile, German Drehmoment, etc.

${ }^{4}$ For example, English bear market, Croatian tržište na kojemu cijene određenih skupina vrijednosnih papira padaju ili se njihov pad očekuje, German Baisse; English six sigma, Croatian metoda poboljšanja kvalitete temeljena na statistici, German Six Sigma; English bait advertising, Croatian prikriveno oglašavanje, German Lockangebote, etc.

${ }^{5}$ For example, English cardiac output, Croatian minutni volument srca, German Herzminutenvolumen; English excess postexercise oxygen consumption, Croatian prekomjerni primitak kisika u oporavku, German Sauerstoffmehraufnahme nach Arbeitsende, etc.

${ }^{6}$ Croatian nogomet, German Fußball

${ }^{7}$ Croatian košarka, German Basketball

${ }^{8}$ Croatian ponuda, German Germ Angebot

${ }^{9}$ Croatian potražnja, German Nachfrage

${ }^{10}$ Croatian strategija razvoja, German Entwicklungsstrategie

${ }^{11}$ German Surfing and Surfen

${ }^{12}$ German Windsurfing and Windsurfen
} 
boarding $^{13}$, i.e. the meaning implied would be similar to the meaning of the second constituent in the term snowboarding - using a board. However, a board is used both in surfing and in windsurfing, so that using a term which designates a long, narrow board on which a surfer or a windsurfer stands to refer to one of the two or either sport is inaccurate. It could be argued that this is the case of pars pro toto (synecdoche) usage, i.e. an example of a metonymic usage of the name of an implement to refer to the whole concept of (a) sport(s) in question. Such usage would not be regarded as incorrect were it not for the fact that two correct terms for the designation of the two sports do exist in Croatian. Eventually, using jargon in an official publication otherwise written in a formal style is only the result of insufficient fastidiousness pertaining to sport-specific terminology.

Correctly used terms both in the English and in the German versions of the previously mentioned brochure speak in favour of the incorrect usage of the two listed terms in the Croatian version of this publication (Table 8). In other words, this one example from the communication level which might be described as being even closer to general language than to language for specific purposes demonstrates the lack of conscientiousness of the supreme importance of the interrelatedness between the reading skill and the knowledge of vocabulary distinctive of a particular domain.

Table 8 Comparison of terms used in the English, German and Croatian version of the brochure published by the Croatian National Tourist Board

\begin{tabular}{|l|l|l|}
\hline $\begin{array}{l}\text { Croatian National Tourist Board } \\
\text { (2018). Croatia - Full of Life: } \\
\text { Discover Your Story. }\end{array}$ & $\begin{array}{l}\text { Kroatische Zentrale für Tourismus } \\
\text { (2018). Kroatien - voller Leben: } \\
\text { entdecke deine Geschichte }\end{array}$ & $\begin{array}{l}\text { Hrvatska turistička zajednica } \\
\text { (2018). Hrvatska - Puna } \\
\text { života: otkrijte svoju priču. }\end{array}$ \\
\hline windsurfing (p. 43) & Windsurfing (p. 43) & windsurfing (p. 43) \\
\hline surfing (p. 51) & Surfen (p. 51) & daskanje (p. 51) \\
\hline windsurfing (p. 66) & Windsurfen (p. 66) & daskanje na vjetru (p. 66) \\
\hline
\end{tabular}

Finally, the survey of the results obtained for the set of speaking sub-skills reveals that the variables like humour in oral business communication in a foreign language and the skill of diplomatic oral communication in a foreign language provide information on the communication style. Therefore, it is conceivable that communication style appeared to be regarded as less required than the sub-skills referred to by some other variables, which consequently resulted in only a fair correlation of the whole speaking skill and the cogency of knowledge of vocabulary. Additionally, the likelihood of interconnectedness of the variable designating pronunciation in a foreign language with the assessed importance of vocabulary knowledge could also prove to be the cause of a poorer correlation between them.

\section{CONCLUSION}

The results of this research indicate the following possible inferences. First, the respondents rated with the highest grades the importance of all sub-skills within the four basic language skills in a foreign language. In the matter of the sequence of skills in

\footnotetext{
${ }^{13}$ The word boarding in the English language does not mean to use a board in order to slide or sail across waves or surf.
} 
terms of their assessed relevance, the results point to the reading skill being regarded as the priority skill a sports manager should possess, followed by the skills of listening, speaking and finally writing. In future it would be interesting to conduct some research with people already working as sports managers - in the Republic of Croatia and elsewhere and to compare the results of such research with the results presented in this article. Second, the respondents rated vocabulary knowledge with the highest grades as well. The third conclusion relates to the fair correlation between the cogency of sports management specificvocabulary knowledge and the relevance of the four basic language skills. Such a finding is not always in compliance with the research results on their relationship in a general foreign language. Unfortunately, the methodology and the results of the research in the current analysis do not determine a clear explanation of the causes of such a finding as feasible, so that they could only be surmised. Some of these causes might be sought in the type of variables included in this research or the roles of sports managers at various levels of management as well as in the actual situations and roles that sports managers have in them. Nevertheless, an accurate and statistically corroborated interpretation of those causes could be obtained only in the forthcoming research. Subsequently, whether deviations in the domain of language for specific purposes herein under consideration pertaining to the interrelation of vocabulary knowledge and the four macro language skills from the results yielded for general language is just an occasional find or whether it appears to be a pattern would be an intriguing subject matter in future research both in the context of sports management and in the context of other domains.

As for the implications that the results of the current analysis might have in the future on devising the guidelines for teaching sports managers a foreign language for specific purposes, one inference is indisputably demanded. Although both all four macro language skills and sports management specific-vocabulary knowledge were rated highest by the respondents, the result which would point to their high interrelatedness was not obtained. Ultimately, this in other words means that in the future both the foreign language teachers and the learners should be encouraged to pay more attention to the interdependence of reading, writing, listening, speaking and the acquisition of vocabulary in the process of teaching/learning a foreign language for specific purposes. Further, more attention should additionally be paid to the fact that the command of general language does not suffice for successful communication in a domain-unique context.

\section{REFERENCES}

Al-Tamimi, Atef Salehand Munir Shuib. "Investigating the English Language Needs of Petroleum Engineering Students at Hadhramout University of Science and Technology," The Asian ESP Journal 6 (2010): 1, 6-34. URL: http://asian-espjournal.com/wp-content/uploads/2016/01/AESP-Voume-6-Issue-1-April-2010.pdf

Ataş, Ufuk. "The Role of Receptive Vocabulary Knowledge in Advanced EFL Listening Comprehension," TESL-EJ 21 (2018): 4, 1-12. URL: https://files.eric.ed.gov/fulltext/ EJ1172563.pdf

Bartolić, Zvonimir and Anita Prelas Kovačević. "Sustav praćenja kompetencija, radne uspješnosti i nagrađivanja radnika," [The System of Monitoring Competence, Working Efficiency and Rewarding the Employees. In Croatian] Praktični menadžment 2 (2011): 2, 81-91. URL: https://hrcak.srce.hr/71851 
Bartoluci, Mato. Ekonomika i menedžment sporta. [Economics and management of sport. In Croatian] Second complemented and revised edition. Zagreb: Informator Zagreb, Kineziološki fakultet Sveučilišta u Zagrebu, 2003.

Basta, Jelena. "Role of Case Studies in Teaching English for Business and Economics," The Journal of Teaching English for Specific and Academic Purposes 5 (2017): 3, 553-566, doi: 10.22190/JTESAP1703553B

Beech, John and Simon Chadwick (Eds.). The Business of Sport Management. Harlow: Pearson Education Limited, 2004.

Bonk, William J. "Second Language Lexical Knowledge and Listening Comprehension," International Journal of Listening 14 (2000): 1, 14-31, doi: 10.1080/10904018.2000. 10499033

Chang, Anna Ching-Shyang. "The Impact of Vocabulary Preparation on L2 Listening Comprehension, Confidence and Strategy Use," System 35 (2007): 4, 534-550, doi: 10.1016/j.system.2007.06.003

Cheng, Yuh-show. "A Measure of Second Language Writing Anxiety: Scale Development and Preliminary Validation," Journal of Second Language Writing 13 (2004): 4, 313-335, doi: 10.1016/j.jslw.2004.07.001

Cheng, Yuh-show, Elaine K. Horwitz and Diane L. Schallert. "Language Anxiety: Differentiating Writing and Speaking Components," Language Learning 49 (2008): 3, 417-446, doi: 10.1111/0023-8333.00095

Çiftçi, Sevda and Nevzat Mirzeoğlu. "The Research of Qualifications of Sport Manager," Procedia - Social and Behavioral Sciences 152 (2014), 740-745, doi: 10.1016/j.sbspro. 2014.09.313

Colton, Theodore. Statistics in Medicine. Boston: Little, Brown and Company, 1974.

Croatian National Tourist Board. Croatia - Full of Life: Discover your story. Zagreb: Hrvatska turistička zajednica, 2018. https://www.htz.hr/sites/default/files/201901/ImageBrosura\%20HTZ-ENG-2018_online.pdf (14 May 2019).

Dabić, Tijana. "Listening - A Neglected Skill in ESP Courses in IT Departments in Serbia," In Linguistics, culture and identity in foreign language education, edited by Azamat Akbarov, 1828-1833. Sarajevo: IBU Publications, 2014.

DeKeyser, Robert M. "What Makes Learning Second-language Grammar Difficult? A Review of Issues," Language Learning 55 (2005): S1, 1-25, doi: 10.1111/j.00238333.2005.00294.x

Dobreva, Albena and Lachezar Popov. "Acquisition of Medical Register Through the Communicative Act of Speaking," JAHR 4 (2013): 7, 479-485.

Dorożyński, Tomasz, Janusz Świerkocki and Wojciech Urbaniak. "Employers Expectations Vis-à-Vis Graduates of Faculties of Economics: Results of a Direct Study," Comparative Economic Research 19 (2016): 2, 93-109, doi: 10.1515/cer-2016-0015

Dudley-Evans, Tony and Maggie Jo St. John. Developments in English for Specific Purposes: A Multi-Disciplinary Approach. Cambridge: Cambridge University Press, 1998.

Goh, Christine Chuen Meng. "A Cognitive Perspective on Language Learners' Listening Comprehension Problems," System 28 (2000): 1, 55-75, doi: 10.1016/S0346251X(99)00060-3

Gupta, Renu. "Writing with a Different Tool," In Computers and language learning, edited by C. S. Ward and W. A. Renandya. Singapore: SEAMEO Regional Language Center, 1998. 
Harkio, Noora and Päivi Pietilä. "The Role of Vocabulary Breadth and Depth in Reading Comprehension: A Quantitative Study of Finnish EFL Learners," Journal of Language Teaching and Research 7 (2015): 6, 1079-1088, doi: 10.17507/jltr.0706.03

Henriksen, Birgit and Lise Danelund. "Studies of Danish L2 Learners' Vocabulary Knowledge and the Lexical Richness of Their Written Production in English," In Lexical issues in L2 writing, edited by Päivi Pietilä, Katalin Doró and Renata Pípalová, 29-56. Newcastle-upon-Tyne: Cambridge Scholars Publishing, 2015. URL: https://gymnasieskolen.dk/sites/default/files/Forskningsartikel.\%20Engelsk\%20ordfor r\%C3\%A5d.\%20Birgit\%20Henriksen.pdf

Hocenski-Dreiseidl, Mirna. "Dvostruka funkcija jezika - opći jezik versus jezik gospodarstva," [The Double Function of Language - General Language versus Language of Economy. In Croatian] Ekonomski vjesnik 19 (2006): 1-2, 101-106. URL: https://hrcak.srce.hr/199710

Hrvatska turistička zajednica. Hrvatska - puna života: otkrijte svoju priču. [Croatia - Full of Life: Discover Your Story. In Croatian] Zagreb: Hrvatska turistička zajednica, 2018. https://www.htz.hr/sites/default/files/2019-01/ImageBrosura\%20HTZ-HRV2018_online.pdf (14 May 2019).

Hsueh-chao, Marcella Hu and I. S. Paul Nation. "Unknown Vocabulary Density and Reading Comprehension," Reading in a Foreign Language 13 (2000): 1, 403-430. URL: https://www.researchgate.net/publication/234651421_Unknown_Vocabulary_Density_an d_Reading_Comprehension

Jelaska, Zrinka. "Jezik, komunikacija i sposobnost: nazivi i bliskoznačnice," [Language, Communication and Competence: Names and Synonyms. In Croatian] Jezik 52 (2005): 4, 128-138. URL: https://hrcak.srce.hr/index.php?show=clanak\&id_clanak_jezik=24203

Jovanova-Simeva, Vesna. "The Connection Between Top Managers Education and Their Successful Sport Clubs Management," Research in Kinesiology 43 (2015): 1, 11-15. URL: https://fsprm.mk/wp-content/uploads/2015/05/Pages-from-RIK-_1_2015_za-email3.pdf

Kaivanpanah, Shiva and Hamed Zandi. "The Role of Depth of Vocabulary Knowledge in Reading Comprehension in an EFL Context," Journal of Applied Sciences 9 (2009): 4, 698-706, doi: 10.3923/jas.2009.698.706

Karakoç, Dilek and Gül Durmuşoğlu Köse. "The Impact of Vocabulary Knowledge on Reading, Writing and Proficiency Scores of EFL Learners," Journal of Language and Linguistic Studies 13 (2017): 1, 352-378. URL: https://files.eric.ed.gov/fulltext/ EJ1140609.pdf

Kiliç, Mehmet. "Vocabulary Knowledge as a Predictor of Performance in Writing and Speaking: A Case of Turkish EFL Learners," PASAA 57 (2019), 133-164. URL: https://files.eric.ed.gov/fulltext/EJ1224421.pdf

Koizumi, Rieand Yo In'nami. "Vocabulary Knowledge and Speaking Proficiency Among Second Language Learners from Novice to Intermediate Levels," Journal of Language Teaching and Research 4 (2013): 5, 900-913, doi: 10.4304/jltr.4.5.900-913

Kroatische Zentrale für Tourismus. Kroatien - voller Leben: entdecke deine Geschichte. [Croatia - Full of Life: Discover Your Story. In German] Zagreb: Hrvatska turistička zajednica, 2018. https://www.htz.hr/sites/default/files/2019-01/imagebrosura\%20htzDE-2018_online.pdf (14 May2019).

Kuna, Dubravka. "Gledišta studenata Filozofskoga fakulteta u Osijeku o nastavi engleskoga kao stranoga jezika," [Views of First Year Students at the Faculty of Philosophy in Osijek 
on the Classes of English As a Foreign Language. In Croatian] Život i škola 53 (2007): 17, 28-36. URL: https://hrcak.srce.hr/index.php?show=clanak\&id_clanak_jezik=32254

Lasswell, Harold D. "The Structure and Function of Communication in Society," In The communication of ideas. A series of addresses, edited by Lyman Bryson, 32-51. New York: Institute for Religious and Social Studies, 1948.

Laufer, Batia. "What Percentage of Text-lexis is Essential for Comprehension?" In Special Language: From Humans to Thinking Machines, edited by Christer Lauren and Marianne Nordman, 316-323. Clevedon/Philadelphia: Multilingual Matters Ltd, 1989. URL: https://www.researchgate.net/publication/248424656_What_percentage_of_text-lexis_is_ essential_for_comprehension

Laufer, Batia. "How Much Lexis is Necessary for Reading Comprehension?" In Vocabulary and applied linguistics, edited by Henri Béjoint and Pierre J. L. Arnaud, 126-132. London: Macmillan Academic and Professional Ltd, 1992, doi: 10.1007/978-1-34912396-4_12

Laufer, Batia. "The Lexical Threshold of Second Language Reading Comprehension: What It Is and How It Relates to L1 Reading Ability," In Approaches to second language acquisition, edited by Kari Sajavaara and Courtney Fairweather, 55-62. Jyväskylä: University of Jyväskylä, 1996.

Laufer, Batia and Geke C. Ravenhorst-Kalovski. "Lexical Threshold Revisited: Lexical Text Coverage, Learners' Vocabulary Size and Reading Comprehension," Reading in a Foreign Language 22 (2010): 1, 15-30. URL: https://files.eric.ed.gov/fulltext/ EJ887873.pdf

Laufer, Batia. "Lexical Thresholds for Reading Comprehension: What They Are and How They Can Be Used for Teaching Purposes," TESOL Quarterly 47 (2013): 4, 867-872, doi: 10.1002/tesq.140

Li, Kezhen Z. "A Study of Vocabulary Knowledge and Reading Comprehension on EFL Chinese Learners," Studies in Literature and Language 10 (2015): 1, 33-40, doi: $10.3968 / 6263$

Marinković, Ivana and Pešić, Dragana. "Teaching Listening to Tourism Students," In Conference proceedings of the $3^{\text {rd }}$ International Conference 'Higher Education in Function of Sustainable Development of Tourism in Serbia and Western Balkans' within 9th International Conference "Science and Higher Education in Function of Sustainable Development - SED 2015”, edited by Milutin Đuričić, Ivana Ćirović and Nenad Milutinović, 397-404. Užice: Business and Technical College of Vocational Studies, 2015.

Marzec-Stawiarska, Małgorzata. "Foreign Language Writing Anxiety Among Adult Advanced Learners of English," Linguistica Silesiana 33 (2012), 221-239. URL: http://journals.pan.pl/Content/89125/mainfile.pdf

Matić, Daniela and Jasminka Bibić. "Uspješnost pisanja na engleskome jeziku kod učenika i studenata," [The Level of Writing Proficiency in Pupils and University Students. In Croatian] Školski vjesnik 58 (2009): 1, 17-31. URL: https://hrcak.srce.hr/82587

Milanović, Dragan, Zrinko Čustonja and Miroslav Hrženjak. "Sport u razvitku hrvatskoga društva," [Sport in the Development of the Croatian Society. In Croatian] In Zbornik radova 25. ljetne škole kineziologa Republike Hrvatske 'Kineziologija i područja edukacije, sporta, sportske rekreacije $i$ kineziterapije $u$ razvitku hrvatskog društva' [Proceedings book of the $25^{\text {th }}$ Summer School of Kinesiologists from the Republic of Croatia 'Kinesiology and Education, Sport, Physical Recreation and Kinesiotherapy in the 
Development of the Croatian Society'], edited by Vladimir Findak, 41-50. Zagreb: Hrvatski kineziološki savez, 2016. URL: https://www.hrks.hr/skole/25_ljetna_skola/41Milanovic.pdf

Milton, James. "Measuring the Contribution of Vocabulary Knowledge to Proficiency in the Four Skills," In L2 vocabulary acquisition, knowledge and use: New perspectives on assessment and corpus analysis, edited by Camilla Bardel, Christina Lindquist and Batia Laufer, 57-78. Amsterdam: European Second Language Association, 2013. URL: https://www.eurosla.org/monographs/EM02/Milton.pdf

Mohammadzadeh, Sakineh, Tahereh Barati and Mohammad Ali Fatemi. "An Investigation into the English Language Needs of Bank Employees of Saderat Bank in Mashhad," Theory and Practice in Language Studies 5 (2015): 8, 1695-1702. doi: http://dx.doi.org/ 10.17507/tpls.0508.21

Morris, Larry W., Mark A. Davis and Calvin H. Hutchings. "Cognitive and Emotional Components of Anxiety: Literature Overview and a Revised Worry-emotionality Scale," Journal of Educational Psychology 73 (1981): 4, 541-555, doi:10.1037/00220663.73.4.541

Nagy, Imola Katalin."English for Special Purposes: Specialized Languages and Problems of Terminology," Acta Universitatis Sapientiae, Philologica 6 (2014): 2, 261-273, doi: 10.1515/ausp-2015-0018

Nation, I. S. Paul. Learning Vocabulary in Another Language. Cambridge: Cambridge University Press, 2001.

Nation, I. S. Paul. "How Large a Vocabulary Is Needed for Reading and Listening?" The Canadian Modern Language Review/Revue canadienne des langues vivantes 63 (2006): 1, 59-82, doi: 10.3138/cmlr.63.1.59

Nation, Paul. "Principles Guiding Vocabulary Learning Through Extensive Reading," Reading in a Foreign Language 27 (2015): 1, 136-145. URL: http://nflrc.hawaii.edu/rfl/ April2015/discussion/nation.pdf

Patekar, Jakob. "Strategije slušanja u nastavi stranoga jezika," [Listening Strategies in the Foreign Language Classroom. In Croatian] Strani jezici 42 (2013): 3, 293-306. URL: https://www.researchgate.net/publication/283781595_Strategije_slusanja_u_nastavi_s tranoga_jezika

Peručić, Doris and Maro Joković. "Marketing menadžment u sportu - primjer dubrovačkih sportskih klubova," [Marketing Management in Sports - Example of Dubrovnik Sport Clubs. In Croatian] Oeconomica Jadertina 8 (2018): 1, 18-29, doi: 10.15291/oec.2729

Prachanant, Nawamin. "Needs Analysis on English Language Use in the Tourism Industry," Procedia - Social and Behavioral Sciences 66 (2012), 117-125, doi: 10.1016/j.sbspro. 2012.11.253

Qian, David D. "Investigating the Relationship Between Vocabulary Knowledge and Academic Reading Performance: An Assessment Perspective," Language Learning 52 (2008): 3, 513-536,doi: 10.1111/1467-9922.00193

Rajprasit, Krich, Panadda Pratoomrat, Tuntiga Wang, Supanit Kulsiri and Saengchan Hemchua. "Use of the English Language Prior to and During Employment: Experiences and Needs of Thai Novice Engineers," Global Journal of Engineering Education 16 (2014): 1, 27-33. URL: https://www.researchgate.net/profile/Krich_ Rajprasit2/publication/285947099_Use_of_the_English_language_prior_to_and_duri ng_employment_Experiences_and_needs_of_Thai_novice_engineers/links/57ab315c 
08ae3765c3b71f46/Use-of-the-English-language-prior-to-and-during-employmentExperiences-and-needs-of-Thai-novice-engineers.pdf

Rashidi, Nasser and Negar Khosravi. "Assessing the Role of Depth and Breadth of Vocabulary Knowledge in Reading Comprehension of Iranian EFL Learners," Journal of Pan-Pacific Association of Applied Linguistics 14 (2010): 1, 81-108. URL: https://citeseerx.ist.psu.edu/viewdoc/download?doi=10.1.1.1007.3096\&rep=rep1\&type= pdf

Schmitt, Norbert, Xiangying Jiang and William Grabe. "The Percentage of Words Known in a Text and Reading Comprehension," The Modern Language Journal 95 (2011): 1, 26-43, doi: 10.1111/j.1540-4781.2011.01146.x

Şen, Yusufand Mesut Kuleli. "The Effect of Vocabulary Size and Vocabulary Depth on Reading in EFL Context," Procedia - Social and Behavioral Sciences 199 (2015), 555-562, doi: 10.1016/j.sbspro.2015.07.546

Smith, Ronald E. and Frank L. Smoll. "Sport Performance Anxiety," In Handbook of social and evaluation anxiety, edited by Harold Leitenberg, 417-454. New York: Plenum Press, 1990.

Stahl, Steven A. "Vocabulary and Readability: How Knowing Word Meanings Affects Comprehension," Topics in Language Disorders 23 (2003): 3, 241-247, doi: 10.1097/ 00011363-200307000-00009

Stæhr, Lars Stenius "Vocabulary Knowledge and Advanced Listening Comprehension in English as a Foreign Language," Studies in Second Language Acquisition 31 (2009): 4, 577-607, doi: 10.1017/S0272263109990039

Szabó, Robert. "Power, Confusion and Offence: A Small-scale Systemic-functional Analysis of Email Communication in English Within Selected German Companies," The Journal of Teaching English for Specific and Academic Purposes 2 (2014): 3, 471-482.

Škorić, Sanela. "Characteristics of Sport Managers and Challenges Facing Sport Organisations," In Proceedings of 9th International Conference: An enterprise Odyssey: Managing change to achieve quality development, edited by Ivana Načinović Braje, Božidar Jaković and Ivana Pavić, 497-503. Zagreb: Ekonomski fakultet, 2018. URL: https://bib.irb.hr/datoteka/944150.45Skoric.pdf

Teng, Feng. "Assessing the Depth and Breadth of Vocabulary Knowledge with Listening Comprehension," PASAA 48 (2014), 29-56. URL: https://files.eric.ed.gov/fulltext/ EJ1077893.pdf

Thitthongkam, Thavorn and John Christopher Walsh. "Roles of Language in Tourism Organisational Management," Asian Journal of Management Research 2 (2010): 1, 184 199. URL: http://citeseerx.ist.psu.edu/viewdoc/download?doi=10.1.1.207.2162\&rep= rep $1 \&$ type $=$ pdf

TIBCO Software Inc. (2018). Statistica for Windows, version 13.5.0.17.

Uchihara, Takumi and Jon Clenton. "Investigating the Role of Vocabulary Size in Second Language Speaking Ability," Language Teaching Research 24 (2020): 4, 540-556, doi: $10.1177 / 1362168818799371$ 
UNWTO. “Tourism's Growth Across All Regions Strengthens Sector's Potential to Contribute to Sustainable Development Agenda," Barometer. 12 December 2019, ttps://www.unwto.org/taxonomy/term/347 (22 October 2020).

van Zeeland, Hilde and Norbert Schmitt. "Lexical Coverage in L1 and L2 Listening Comprehension: The Same or Different from Reading Comprehension?" Applied Linguistics 34 (2012): 4, 457-479, doi: 10.1093/applin/ams074

Wilson, Adam. "Adapting English for the Specific Purpose of Tourism: A Study of Communication Strategies in Face-to-face Encounters in a French Tourist Office," ASp 73 (2018), 53-73, doi: 0.4000/ASP.5118

$\mathrm{Wu}$, Rachel Yi-fen and Joyce Shao Chin. "An Investigation into the English Language Needs of Banking and Finance Professionals in Taiwan," In Proceedings of the 12th Academic Forum on English Language Testing in Asia, 73-87. Taipei: The Language Training and Testing Center, 2010. URL: https://www.lttc.ntu.edu.tw/TLResource/Needs_Analysis_of_ Banking_and_Financial_Professionals.pdf

Xhaferi, Brikena and Gezim Xhaferi. "The English Language Skills in ESP for Law Course," Revista de lenguas para fines específicos 17 (2011), 431-448. URL: https://www.researchgate.net/publication/285001536_The_English_language_skills_in_ ESP_for_law_course

Yukl, Garry. Leadership in Organizations. Upper Saddle River: Prentice Hall, 1998.

Yüksel, İlknur. "The Key to Second Language Writing Performance: The Relationship Between Lexical Competence and Writing," Sino-US English Teaching 12 (2015): 8, 539-555, doi: 10.17265/1539-8072/2015.08.001

Zhang, Pengchong and Suzanne Graham. "Learning Vocabulary Through Listening: The Role of Vocabulary Knowledge and Listening Proficiency," Language Learning 70 (2020): 4, doi: 10.1111/lang.12411 